N. R. MATKOVSKA (Ivano-Frankivsk)

\title{
CHANGES IN THE HAEMOSTASIS SYSTEM UNDER THE INFLUENCE OF TREATMENT OF PATIENTS WITH ALCOHOLIC LIVER CIRRHOSIS IN COMBINATION WITH OBESITY USING ADEMETHIONINE, ARGININE GLUTAMATE AND ROSUVASTATIN
}

\author{
Ivano-Frankivsk national medical university<nmail4you@gmail.com>
}

\begin{abstract}
Introduction. The urgency of the problem of liver cirrhosis (LC) is caused by the increase in morbidity, prevalence, life-threatening complications, disability and increasing mortality of able-bodied population. The aim of the study was to examine the effect of complex treatment with ademethionine, arginine glutamate and rosuvastatin on changes in the haemostasis systemin patients with alcoholic liver cirrhosis (ALC) in combination with obesity. Research methods. The study included 105 patients diagnosed with ALC in combination with obesity. The assessment of the effectiveness of a three-month treatment regimen with ademethionine, arginine glutamate and rosuvastatin in obese patients with alcoholic liver cirrhosis (ALC) included indicators of synthetic liver function and hemostasis (total protein, albumin, fibrinogen, platelet count, factor Von Willebrand factor, activated partial thromboplastin time (APTT), thrombin time (TT), international normalized ratio (INR), prothrombin index (PI), D-dimer, tissue plasminogen activator (tPA), 1 plasminogen activator (PAI-1), tPA/PAI-1 index, asymmetric dimethylarginine (ADMA)), as well as liver cirrhosis severity (Child-Pugh score) and 3-month MELD mortality score. Results. Decreased levels of total protein, albumin, fibrinogen, $P I$, platelet count and increased levels of Von Willebrand factor, prothrombin time (PT), APTT, TT, INR, D-dimer, tPA and PAI-1, ADMA were revealed. Such changes worsened with increasing liver cirrhosis decompensation and were accompanied by an increase in the Child-Pugh and MELD scores $(P<0.05)$. There was a more pronounced increase in levels of PAI-1 than $T P A$, that was accompanied by a decrease in $t P A / P A I-1$ index. A number of researchers indicate that an increase in PAI-1 levels can cause a hypercoagulable state, so its increase with a decrease in tPA/PAI-1 index in patients with ALC in combination with obesity indicates a risk of thrombogenic conditions. This is also evidenced by the increasing number of D-dimers. Therefore, the fibrinolytic/antifibrinolytic factors should be considered in the treatment of such patients to prevent LC complications. Conclusions. The inclusion of ademethionine, arginine glutamate and rosuvastatin in the treatment regimen for 3 months improved the levels of total protein, albumin, fibrinogen, PI, platelet count, Von Willebrand factor, PT, APTT, TT, INR, Ddimer, tPA and PAI-1, ADMA, which was accompanied by a decrease in Child-Pugh severity score and MELD 3-month mortality score.
\end{abstract}

Key words: alcoholic liver disease; liver cirrhosis; obesity; haemostasis.

Introduction. The urgency of the problem of liver cirrhosis (LC) is caused by the increase in morbidity, prevalence, life-threatening complications, disability and increasing mortality of able-bodied population [6]. The frequency of detection of this pathology in the world is $11 \%$, including Europe and the USA - from 3 to $8 \%$ [8]. According to various authors, $0.1 \%$ of the European population suffer from LC; 14-30 new cases of LC for 100 thousand people and about 170 thousand fatal cases are registered every year. Annually, about 2 million people die due to complications of LC - this is $71 \%$ of all digestive organs diseases $[7,12,15]$.

The liver plays a central role in the hemostatic system as it synthesizes the majority of coagulation factors and proteins involved in fibrinolysis. Chronic liver 
disease is characterized by a defective hepatic synthesis of clotting factors and thrombocytopenia, largely caused by portal hypertension and by hyperfibrinolysis that may further contribute to alterations in hemostasis and may cause intra- and extrahepatic thrombogenic conditions [2, 3, 10, 11].

Standard coagulation tests, such as international normalized ratio (INR), prothrombin time (PT), activated partial thromboplastin time (APTT) are not sufficient in prediction of bleeding or thrombotic complications of LC $[1,4,14]$.

The regulation of normal blood flow is performed by a fibrinolytic system, the main enzyme of which is plasmin. It is made up of plasminogen with serine proteases, such as tissue or urokinase plasminogen activator (t-PA and u-PA, respectively). All proteins involved in fibrinolysis, except t-PA andtype 1 plasminogen activator (PAI-1), are synthesized in the liver. The concentration of plasminogen, $\alpha 2$-antiplasmin, factor XIII and inhibitor of Thrombin Activatable Fibrinolysis (TAFI) is reduced at LC. Fibrinolysis is inhibited by PAI-1 and TAFI, the amount of which increases in the blood $[5,8,9]$. It is proved that the increase of PAI- 1 , which is considered as a key component of the system of fibrinolysis, in liver diseases correlates with the parameters of the systemic inflammatory process, endothelial dysfunction and fibrogenesis $[6,13]$.

Due to the disorder of the hemostasis system the growing incidence of ALD, methods are being sought to prevent the progression of the pathological process in the liver, the occurrence of complications, to improve the liver function and to improve the quality of life of such patients.

The aim of the study was to examine the effect of complex treatment with ademethionine, arginine glutamate and rosuvastatin on changes in the haemostasis systemin patients with alcoholic liver cirrhosis (ALC) in combination with obesity.

Research methods. The study included 105 patients diagnosed with ALC in combination with obesity, including 18 women and 138 men aged $(46.1 \pm 8.5)$ years and a median duration of disease $(5.3 \pm 2.6)$ years. Patients were divided into subgroups depending on the stage of Child-Pugh decompensation: class A $(n=39)$, class $\mathrm{B}(n=34)$, class C $(n=32)$. Depending on the applied treatment, all patients were divided into groups: patients of group I (IA $(n=22)$, IB $(n=18)$ and IC $(n=16))$ received basic therapy; patients of group II - IIA $(n=17)$, IIB $(n=16)$ and IIC $(n=16)$, additionally received ademethionine, arginine glutamate and rosuvastatin.

Group IIA in addition to the basic treatment, received intravenously $500 \mathrm{mg}$ of ademethionine per day during two weeks, followed by oral administration of 500 $\mathrm{mg}$ of ademethionine, $1500 \mathrm{mg}$ of arginine glutamate per day for 12 weeks.

Group IIB in addition to the basic treatment, received intravenously $1000 \mathrm{mg}$ of ademethionine per day for two weeks, followed by oral administration of $1000 \mathrm{mg}$ of ademethionine and $3000 \mathrm{mg}$ of arginine glutamate for 12 weeks.

Group IIC in addition to their basic treatment, received intravenously $1000 \mathrm{mg}$ of ademethionine per day for two weeks, followed by oral administration of $1500 \mathrm{mg}$ of ademethionine and $4500 \mathrm{mg}$ of arginine glutamate per day for 12 weeks.

Groups IIA and IIB received additionally $20 \mathrm{mg}$ of rosuvastatin orally per day for 12 weeks, and patients of group IIC received an additional $10 \mathrm{mg}$ of rosuvastatin orally per day for 12 weeks.

Diagnosis was verified using clinical and laboratory-instrumental methods in accordance with the order of the Ministry of Health of Ukraine No. 826 dated November 6, 2014, adapted clinical guidelines "Non-Alcoholic Fatty Liver Disease", 2014, adapted clinical guidelines "Alcoholic Liver Disease", 2014, adapted clinical guidelines " Liver Cirrhosis, 2017 (State Expert Centre of the Ministry of Health of Ukraine, Ukrainian Gastroenterology Association, Kyiv), recommendations of the European Association for the Study of Liver, Diabetes and Obesity (EASL-EASD-EASO, 2016).

Exclusion criteria were liver cirrhosis of the viral, toxic and autoimmune genesis, metabolic diseases of the liver, oncological diseases, and the lack of indi- 
vidual consent of the patient to conduct the study. All patients were matched according to age and sex. The research was carried out in accordance with the ethical principles of conducting scientific research and principles of the Helsinki Declaration.

The protein-synthetic function of the liver was determined by the level of albumin, fibrinogen in blood, prothrombin index (PI) and INR, which were measured using conventional methods. PT, APTT, thrombin time (TT) and fibrinogen were measured using conventional methods. The content of plasmin degradation product of the insoluble D-dimer product fibrin (DD) was measured by immunoassay using "Technozym D-dimer ELISA" ("Technoclone", Austria). The Willebrand factor was determined by the method based on the stimulation of ristomycin aggregation (suspension of fixed donor platelets by the Willebrand factor of the study without platelet plasma). Calculation was carried out on a calibration curve built on logarithmic paper. For its construction, 20 donor platelet-poor plasmas were diluted $1: 1,1: 2$, $1: 4,1: 5$, corresponding to a concentration of $100 \%, 50 \%, 25 \%, 12.5 \%$ of the Willebrand factor in blood plasma. To increase the accuracy of the analysis, two parallel samples were tested, followed by an average value calculation. The t-PA level in the blood was determined by the immunoassay method using the t-PA Combi Actibind ELISA kits ("Technoclone GmbH", Austria). The PAI-1 level in the blood was determined by immunoassay using human PAI-1 Antigen ELISA kits ("Technoclone", Austria). The endothelial dysfunction was studied by content of asymmetric dimethylarginine (ADMA) in the blood, determined by the immune enzymatic method using ADMA High Sensitive ELISA (Biovendor, Czech Republic).

The severity of the LC was assessed using the Child-Pugh score and the MELD score (Mayo Endstage Liver Disease, 2001). The control group consisted of 20 healthy individuals, who were age and gender matched. Assessment of patients was performed before and after 3 months from the beginning of treatment.

Statistical processing of the obtained results was carried out using the software package Statistica v. 12.0 (StatSoft, USA, trial) and Microsoft Excel. The average values are presented in the form $(M \pm m)$, where " $M$ " is the average value of the indicator, " $m$ " is the standard error of the average. Student's $t$-test was used to determine the significance of differences between groups in a distribution close to normal. Differences at $\mathrm{P}<0.05$ were considered statistically significant.

Results and discussion. In patients with LC in combination with obesity, changes in synthetic liver function and hemostasis are characterized by decreased levels of total protein, albumin, fibrinogen, PI, platelet count, accompanied by an increase in Von Willebrand factor, PT, APTT, TT, INR, D-dimer, tPA and PAI-1 and ADMA. Such rates deteriorated with increasing LC decompensation, which is accompanied by an increase in the Child-Pugh and MELD scores $(\mathrm{P}<0.05)$ (Tabl. 1-3).

After the course of treatment in patients of group II at the stage of compensation, the rates of total protein, albumin, fibrinogen, platelet count, Von Willebrand factor, PT, APTT, TT, INR, PI, D-dimer, tPA, PAI-1, tPA/PAI-1, ADMA, Child-Pugh and MELD scores improved significantly $(\mathrm{P}<0.05)$, while in patients of group I they worsened, but no significant difference compared to baseline was found $(\mathrm{P}>0.05)$. In patients of group II at the stage of compensation after treatment, Von Willebrand factor, D-dimer, tPA, PAI-1 and ADMA differed from those in the control group $(\mathrm{P}<0.05)$, indicating a higher sensitivity of such indicators to disorders in the system of blood clotting compared to routine rates.

At the stage of subcompensation after treatment in patients of group II, the total protein, albumin, fibrinogen, platelet count, Von Willebrand factor, PT, APTT, TT, INR, PI, D-dimer, tPA, PAI-1, tPA/PAI-1, ADMA, Child-Pugh and MELD scores significantly improved, but differed from those in the control group $(\mathrm{P}<0.05)$. In patients receiving basic treatment, they worsened, but no significant difference compared to baseline was found $(\mathrm{P}>0.05)$. 
Table 1. Dynamics of haemostasis under the influence of complex treatment with ademethionine, arginine glutamate and rosuvastatin in patients with alcoholic liver cirrhosis in combination with obesity with stage $A$ according to the Child-Pugh score $(M \pm m)$

\begin{tabular}{|c|c|c|c|c|c|}
\hline \multirow[b]{2}{*}{ Values } & \multirow{2}{*}{$\begin{array}{l}\text { Control } \\
(n=20)\end{array}$} & \multicolumn{2}{|c|}{ IA } & \multicolumn{2}{|c|}{ IIA } \\
\hline & & $\begin{array}{l}\text { Before } \\
\text { treatment }\end{array}$ & $\begin{array}{l}\text { After } 3 \text { month } \\
\text { treatment }\end{array}$ & $\begin{array}{c}\text { Before } \\
\text { treatment }\end{array}$ & $\begin{array}{c}\text { After } 3 \text { month } \\
\text { treatment }\end{array}$ \\
\hline Total protein, g/l & $74.67 \pm 3.27$ & $58.79 \pm 1.87^{\Delta}$ & $59.52 \pm 1.54^{\Delta}$ & $58.71 \pm 1.94^{\Delta}$ & $69.71 \pm 1.32^{* \star}$ \\
\hline Albumin, $\mathrm{g} / 1$ & $47.83 \pm 3.26$ & $39.61 \pm 1.12^{\Delta}$ & $40.16 \pm 1.18^{\Delta}$ & $39.54 \pm 1.09^{\Delta}$ & $45.61 \pm 1.15^{* \star}$ \\
\hline Fibrinogen, g/1 & $3.66 \pm 0.27$ & $2.42 \pm 0.06^{\Delta}$ & $2.33 \pm 0.09^{\Delta}$ & $2.38 \pm 0.07^{\Delta}$ & $3.45 \pm 0.12^{*}$ \\
\hline Platelets, $* 10^{9} / 1$ & $254.13 \pm 18.63$ & $166.58 \pm 11.28^{\Delta}$ & $163.42 \pm 10.52^{\Delta}$ & $160.84 \pm 12.31^{\Delta}$ & $212.83 \pm 13.57$ \\
\hline $\begin{array}{l}\text { Von Willebrand } \\
\text { factor, } \%\end{array}$ & $102.31 \pm 4.51$ & $131.26 \pm 7.42^{\Delta}$ & $142.26 \pm 6.57^{\Delta}$ & $133.57 \pm 6.91^{\Delta}$ & $117.72 \pm 5.36^{\Delta * \bullet}$ \\
\hline PT $(\mathrm{sec})$ & $11.27 \pm 0.69$ & $15.23 \pm 0.79^{\Delta}$ & $16.14 \pm 0.67^{\Delta}$ & $15.29 \pm 0.65^{\Delta}$ & $13.81 \pm 0.52^{* \star}$ \\
\hline APTT (sec) & $27.76 \pm 1.35$ & $36.43 \pm 1.46^{\Delta}$ & $38.02 \pm 0.84^{\Delta}$ & $36.49 \pm 1.51^{\Delta}$ & $29.75 \pm 0.91^{* \bullet}$ \\
\hline $\mathrm{TT}(\mathrm{sec})$ & $16.79 \pm 0.82$ & $20.19 \pm 0.67^{\Delta}$ & $21.07 \pm 0.77^{\Delta}$ & $20.23 \pm 0.72^{\Delta}$ & $17.93 \pm 0.72^{* \bullet}$ \\
\hline INR & $1.21 \pm 0.08$ & $1.35 \pm 0.05^{\Delta}$ & $1.43 \pm 0.07^{\Delta}$ & $1.36 \pm 0.06^{\Delta}$ & $1.23 \pm 0.04^{* \bullet}$ \\
\hline PI, \% & $88.52 \pm 5.73$ & $73.99 \pm 1.34^{\Delta}$ & $69.84 \pm 0.79^{\Delta}$ & $73.72 \pm 1.57^{\Delta}$ & $81.63 \pm 1.72 * \star$ \\
\hline D-dimer, $\mathrm{ng} / \mathrm{ml}$ & $0.29 \pm 0.01$ & $0.48 \pm 0.02^{\Delta}$ & $0.52 \pm 0.03^{\Delta}$ & $0.51 \pm 0.04^{\Delta}$ & $0.38 \pm 0.05^{\Delta * \star}$ \\
\hline $\mathrm{tPA}, \mathrm{ng} / \mathrm{ml}$ & $16.30 \pm 1.21$ & $34.65 \pm 2.62^{\Delta}$ & $37.13 \pm 3.05^{\Delta}$ & $35.21 \pm 2.24^{\Delta}$ & $21.54 \pm 1.17^{\Delta * \bullet}$ \\
\hline PAI-1, ng/ml & $18,36 \pm 0,72$ & $58,22 \pm 2,31^{\Delta}$ & $64.07 \pm 3.82^{\Delta}$ & $59,18 \pm 2,68^{\Delta}$ & $24.98 \pm 1.24^{\Delta * \bullet}$ \\
\hline tPA/PAI-1 & $0,89 \pm 0.03$ & $0,59 \pm 0.02^{\Delta}$ & $0,58 \pm 0.03^{\Delta}$ & $0,59 \pm 0.03^{\Delta}$ & $0,86 \pm 0.02 * \bullet$ \\
\hline ADMA, mmol/1 & $0,46 \pm 0,01$ & $3.39 \pm 0.08^{\Delta}$ & $3.54 \pm 0.11^{\Delta}$ & $3.42 \pm 0.10^{\Delta}$ & $1.18 \pm 0.07^{\Delta * \bullet}$ \\
\hline Child-Pugh score & - & $5.75 \pm 0.11^{\Delta}$ & $6.24 \pm 0.16^{\star}$ & $5.82 \pm 0.16^{\Delta}$ & $5.09 \pm 0.08^{\Delta * \star}$ \\
\hline MELD score & - & $13.59 \pm 0.76^{\Delta}$ & $15.21 \pm 0.81^{\star}$ & $13.65 \pm 0.81^{\Delta}$ & $6.79 \pm 0.34^{\Delta * \star}$ \\
\hline
\end{tabular}

Notes: $\Delta$ - the probability of differences in values compared with the control group $(\mathrm{P}<0.05)$; * - the probability of differences in values between groups I and II $(\mathrm{P}<0.05)$; - the probability of differences in values before and after treatment $(\mathrm{P}<0.05)$.

Table 2. Dynamics of haemostasis under the influence of complex treatment with ademethionine, arginine glutamate and rosuvastatin in patients with alcoholic liver cirrhosis in combination with obesity with stage $\mathbf{B}$ according to the Child-Pugh score $(M \pm m)$

\begin{tabular}{|c|c|c|c|c|c|}
\hline \multirow[b]{2}{*}{ Values } & \multirow{2}{*}{$\begin{array}{l}\text { Control } \\
(n=20)\end{array}$} & \multicolumn{2}{|c|}{ IB } & \multicolumn{2}{|c|}{ IIB } \\
\hline & & $\begin{array}{c}\text { Before } \\
\text { treatment }\end{array}$ & $\begin{array}{c}\text { After } 3 \text { month } \\
\text { treatment }\end{array}$ & $\begin{array}{c}\text { Before } \\
\text { treatment }\end{array}$ & $\begin{array}{c}\text { After } 3 \text { month } \\
\text { treatment }\end{array}$ \\
\hline Total protein, $\mathrm{g} / \mathrm{l}$ & $74.67 \pm 4.27$ & $51.96 \pm 1.84^{\Delta}$ & $48.61 \pm 1.79^{\Delta}$ & $52.04 \pm 1.92^{\Delta}$ & $57.46 \pm 1.73^{\Delta * \bullet}$ \\
\hline Albumin, $\mathrm{g} / 1$ & $47.83 \pm 4.26$ & $31.47 \pm 1.31^{\Delta}$ & $28.93 \pm 1.84^{\Delta}$ & $31.39 \pm 1.38^{\Delta}$ & $37.96 \pm 1.82^{\Delta * \star}$ \\
\hline Fibrinogen, $\mathrm{g} / \mathrm{l}$ & $3.66 \pm 0.27$ & $1.72 \pm 0.11^{\Delta}$ & $1.59 \pm 0.09^{\Delta}$ & $1.69 \pm 0.09^{\Delta}$ & $2.37 \pm 0.12^{\Delta * \star}$ \\
\hline Platelets, $* 10^{9} / 1$ & $254.13 \pm 15.63$ & $131.16 \pm 9.41^{\Delta}$ & $127.31 \pm 6.87^{\Delta}$ & $129.76 \pm 10.04^{\Delta}$ & $168.57 \pm 9.64^{\Delta * \star}$ \\
\hline $\begin{array}{l}\text { Von Willebrand } \\
\text { factor, \% }\end{array}$ & $102.31 \pm 4.51$ & $169.46 \pm 5.74^{\Delta}$ & $173.34 \pm 4.62^{\Delta}$ & $170.52 \pm 5.68^{\Delta}$ & $136.63 \pm 3.89^{\Delta * *}$ \\
\hline PT $(\mathrm{sec})$ & $11.27 \pm 0.69$ & $16.98 \pm 0.67^{\Delta}$ & $17.83 \pm 1.05^{\Delta}$ & $17.06 \pm 0.81^{\Delta}$ & $15.26 \pm 0.93^{\Delta * \star}$ \\
\hline APTT (sec) & $27.76 \pm 1.35$ & $42.57 \pm 1.49^{\Delta}$ & $45.69 \pm 1.73^{\Delta}$ & $42.63 \pm 1.52^{\Delta}$ & $36.29 \pm 1.63^{\Delta * \star}$ \\
\hline $\mathrm{TT}(\mathrm{sec})$ & $16.79 \pm 0.82$ & $23.29 \pm 1.15^{\Delta}$ & $23.97 \pm 0.84^{\Delta}$ & $23.31 \pm 1.11^{\Delta}$ & $19.87 \pm 0.76^{\Delta * \star}$ \\
\hline INR & $1.21 \pm 0.08$ & $1.51 \pm 0.06^{\Delta}$ & $1.58 \pm 0.08^{\Delta}$ & $1.51 \pm 0.05^{\Delta}$ & $1.36 \pm 0.05^{\Delta * \bullet}$ \\
\hline PI, \% & $88.52 \pm 5.73$ & $66.38 \pm 2.47^{\Delta}$ & $63.21 \pm 2.85^{\Delta}$ & $66.06 \pm 2.32^{\Delta}$ & $73.84 \pm 2.88^{\Delta * \star}$ \\
\hline D-dimer, $\mathrm{ng} / \mathrm{ml}$ & $0.29 \pm 0.01$ & $0.69 \pm 0.04^{\Delta}$ & $0.75 \pm 0.03^{\Delta}$ & $0.71 \pm 0.03^{\Delta}$ & $0.58 \pm 0.04^{\Delta * *}$ \\
\hline $\mathrm{tPA}, \mathrm{ng} / \mathrm{ml}$ & $16.30 \pm 1.2$ & $48.56 \pm 1.75^{\Delta}$ & $50.31 \pm 1.59^{\Delta}$ & $48.87 \pm 1.68^{\Delta}$ & $39.56 \pm 1.66^{\Delta * \star}$ \\
\hline PAI-1, ng/ml & $18,36 \pm 0,72$ & $87,72 \pm 1,84^{\Delta}$ & $91,64 \pm 2,13^{\Delta}$ & $88,02 \pm 1,79^{\Delta}$ & $63,54 \pm 2,81^{\Delta * \star}$ \\
\hline tPA/PAI-1 & $0,89 \pm 0.03$ & $0,55 \pm 0.02^{\Delta}$ & $0,55 \pm 0.02^{\Delta}$ & $0,55 \pm 0.03^{\Delta}$ & $0,63 \pm 0.03^{\Delta * \bullet}$ \\
\hline ADMA, mmol/1 & $0,46 \pm 0,01$ & $4.27 \pm 0.14^{\Delta}$ & $4,50 \pm 0,12^{\Delta}$ & $4.30 \pm 0.11^{\Delta}$ & $3,75 \pm 0,07^{\Delta * \bullet}$ \\
\hline Child-Pugh score & - & $8.72 \pm 0.18^{\Delta}$ & $12.68 \pm 0.14^{\star}$ & $8.83 \pm 0.19^{\Delta}$ & $5.81 \pm 0.15^{\Delta * \bullet}$ \\
\hline MELD score & - & $19.76 \pm 0.83^{\Delta}$ & $25.12 \pm 0.72$ & $19.91 \pm 0.38^{\Delta}$ & $9.43 \pm 0.64^{\Delta * \bullet}$ \\
\hline
\end{tabular}

Notes: $\Delta$ - the probability of differences in values compared with the control group $(\mathrm{P}<0.05)$; * - the probability of differences in values between groups I and II $(\mathrm{P}<0.05)$; - the probability of differences in values before and after treatment $(\mathrm{P}<0.05)$. 
Table 3. Dynamics of haemostasis under the influence of complex treatment with ademethionine, arginine glutamate and rosuvastatin in patients with alcoholic liver cirrhosis in combination with obesity with stage $\mathrm{C}$ according to the Child-Pugh score $(M \pm m)$

\begin{tabular}{|c|c|c|c|c|c|}
\hline \multirow[b]{2}{*}{ Values } & \multirow{2}{*}{$\begin{array}{l}\text { Control } \\
(n=20)\end{array}$} & \multicolumn{2}{|c|}{$\mathrm{IC}$} & \multicolumn{2}{|c|}{ IIC } \\
\hline & & $\begin{array}{l}\text { Before } \\
\text { treatment }\end{array}$ & $\begin{array}{c}\text { After } 3 \text { month } \\
\text { treatment }\end{array}$ & $\begin{array}{l}\text { Before } \\
\text { treatment }\end{array}$ & $\begin{array}{c}\text { After } 3 \text { month } \\
\text { treatment }\end{array}$ \\
\hline Total protein, $\mathrm{g} / \mathrm{l}$ & $74.67 \pm 4.27$ & $42.24 \pm 1.47^{\Delta}$ & $39.16 \pm 1.23^{\Delta \star}$ & $42.19 \pm 1.51^{\Delta}$ & $51.43 \pm 1.27^{\Delta * \star}$ \\
\hline Albumin, g/1 & $47.83 \pm 4.26$ & $24.13 \pm 1.18^{\Delta}$ & $21.74 \pm 1.12^{\Delta \bullet}$ & $24.09 \pm 1.22^{\Delta}$ & $27.74 \pm 1.36^{\Delta * \star}$ \\
\hline Fibrinogen, $g / 1$ & $3.66 \pm 0.27$ & $1.41 \pm 0.10^{\Delta}$ & $1.21 \pm 0.07^{\Delta}$ & $1.38 \pm 0.09^{\Delta}$ & $1.65 \pm 0.11^{\Delta * \bullet}$ \\
\hline Platelets, $* 10^{9} / 1$ & $254.13 \pm 15.63$ & $93.78 \pm 4.96^{\Delta}$ & $84.32 \pm 3.05^{\Delta \bullet}$ & $93.95 \pm 5.13^{\Delta}$ & $114.13 \pm 7.82^{\Delta * \star}$ \\
\hline $\begin{array}{l}\text { Von Willebrand } \\
\text { factor, } \%\end{array}$ & $102.31 \pm 4.51$ & $215.27 \pm 7.13^{\Delta}$ & $231.54 \pm 6.71^{\Delta}$ & $217.19 \pm 6.89^{\Delta}$ & $159.32 \pm 6.63^{\Delta * \star}$ \\
\hline PT (sec) & $11.27 \pm 0.69$ & $22.16 \pm 0.92^{\Delta}$ & $25.47 \pm 1.29^{\Delta \bullet}$ & $22.13 \pm 0.88^{\Delta}$ & $18.13 \pm 1.37^{\Delta * \star}$ \\
\hline APTT (sec) & $27.76 \pm 1.35$ & $55.47 \pm 1.87^{\Delta}$ & $59.93 \pm 1.54^{\Delta \bullet}$ & $55.43 \pm 1.92^{\Delta}$ & $41.96 \pm 1.64^{\Delta * \star}$ \\
\hline $\mathrm{TT}(\mathrm{sec})$ & $16.79 \pm 0.82$ & $25.73 \pm 1.06^{\Delta}$ & $28.07 \pm 1.16^{\Delta \bullet}$ & $25.71 \pm 0.95^{\Delta}$ & $23.51 \pm 1.02^{\Delta * \star}$ \\
\hline INR & $1.21 \pm 0.08$ & $1.97 \pm 0.09^{\Delta}$ & $2.26 \pm 0.12^{\Delta \bullet}$ & $1.96 \pm 0.08^{\Delta}$ & $1.61 \pm 0.07^{\Delta * \bullet}$ \\
\hline PI, \% & $88.52 \pm 5.73$ & $50.86 \pm 1.32^{\Delta}$ & $44.25 \pm 1.23^{\Delta \bullet}$ & $50.93 \pm 1.44^{\Delta}$ & $62.16 \pm 1.19^{\Delta * \star}$ \\
\hline D-dimer, ng/ml & $0.29 \pm 0.01$ & $0.93 \pm 0.02^{\Delta}$ & $0.98 \pm 0.02^{\Delta \bullet}$ & $0.95 \pm 0.05^{\Delta}$ & $0.81 \pm 0.02^{\Delta * \bullet}$ \\
\hline $\mathrm{tPA}, \mathrm{ng} / \mathrm{ml}$ & $16.30 \pm 1.2$ & $56.22 \pm 2.04^{\Delta}$ & $60.84 \pm 1.77^{\Delta \bullet}$ & $56.28 \pm 2.11^{\Delta}$ & $52.75 \pm 1.64^{\Delta * \star}$ \\
\hline PAI-1, ng/ml & $18,36 \pm 0,72$ & $99,32 \pm 2,23^{\Delta}$ & $107.27 \pm 2.14^{\Delta}$ & $99,25 \pm 2,16^{\Delta}$ & $87.21 \pm 2.09^{\Delta * \star}$ \\
\hline tPA/PAI-1 & $0,89 \pm 0.03$ & $0,57 \pm 0.02^{\Delta}$ & $0,57 \pm 0.01^{\Delta}$ & $0,57 \pm 0.01^{\Delta}$ & $0,61 \pm 0.02^{\Delta * \bullet}$ \\
\hline ADMA, mmol/1 & $0,46 \pm 0,01$ & $5.12 \pm 0.10^{\Delta}$ & $5.43 \pm 0.09^{\Delta}$ & $5.10 \pm 0.12^{\Delta}$ & $4.54 \pm 0.07^{\Delta * \bullet}$ \\
\hline $\begin{array}{l}\text { Child-Pugh } \\
\text { score }\end{array}$ & - & $14.13 \pm 0.72^{\Delta}$ & $15.94 \pm 0.82^{\Delta \bullet}$ & $14.4 \pm 0.89^{\Delta}$ & $6.72 \pm 0.34^{\Delta *}$ \\
\hline $\begin{array}{l}\text { MELD } \\
\text { score }\end{array}$ & - & $27.56 \pm 1.22^{\Delta}$ & $30.06 \pm 1.37^{\Delta}$ & $28.07 \pm 1.14^{\Delta}$ & $12.49 \pm 0.95^{\Delta * *}$ \\
\hline
\end{tabular}

Notes: $\Delta$ - the probability of differences in values compared with the control group $(\mathrm{P}<0.05)$; * - the probability of differences in values between groups I and II $(\mathrm{P}<0.05) ;-$ the probability of differences in values before and after treatment $(\mathrm{P}<0.05)$.

At the stage of decompensation after treatment in patients of group II, the total protein, albumin, fibrinogen, platelet count, Von Willebrand factor, PT, APTT, TT, INR, PI, D-dimer, tPA, PAI-1, tPA/PAI-1, ADMA, Child-Pugh and MELD scores significantly improved and differed from those in the control group $(\mathrm{P}<0.05)$. At the stage of decompensation after treatment, in patients of group I indicators of total protein, albumin, fibrinogen, platelet count, Von Willebrand factor, PT, APTT, TT, INR, PI, D-dimer, tPA, PAI-1, tPA/PAI-1, ADMA, Child-Pugh and MELD scores significantly deteriorated compared to baseline, indicating profound progressive impairment of synthetic liver function and hemostasis system, which can be considered prognostically unfavorable $(\mathrm{P}<0.05)$.

The liver has a number of hemostatic roles including the production of most coagulation factors and inhibitors, as well as fibrinolytic factors. This stability is disrupted by the effects of advanced liver disease in the form of decreased synthesis of coagulation factors, inhibitors, abnormal clotting factors, abnormalities of fibrinolytic activity, disseminated intravascular coagulation and platelet function defects. In end-stage liver disease several pathophysiological mechanisms, especially profound endothelial dysfunction (ED), may be responsible for a hypercoagulable state with the potential for severe thrombotic complications. ED is responsible for increased production of liver independent coagulation factors such as von Willebrand factor, factor VIII), and PAI-1. These alterations, in combination with changes in the balance of coagulation/anticoagulation and fibrinolytic/antifibrinolytic factors, affect all levels of the hemostatic system. Standard laboratory coagulation tests are unable to predict bleeding and are inadequate for the assessment of hemostatic status in these patients. 
The assessment of the effectiveness of a three-month treatment regimen with ademethionine, arginine glutamate and rosuvastatin in obese patients with ALC included indicators of synthetic liver function and hemostasis (total protein, albumin, fibrinogen, platelet count, Von Willebrand factor, APTT, TT, INR, PI, D-dimer, tPA, PAI-1, tPA/PAI-1, ADMA), as well as LC severity (Child-Pugh score) and 3-month MELD mortality score.

Decreased levels of total protein, albumin, fibrinogen, PI, platelet count and increased levels of Von Willebrand factor, PT, APTT, TT, INR, D-dimer, tPA and PAI-1, ADMA were revealed. Such changes worsened with increasing LC decompensation and were accompanied by an increase in the Child-Pugh and MELD scores $(\mathrm{P}<0.05)$.

There was a more pronounced increase in levels of PAI-1 than tPA, that was accompanied by a decrease in tPA/PAI-1 index. A number of researchers indicate that an increase in IAP-1 levels can cause a hypercoagulable state, so its increase with a decrease in tPA/PAI-1 index in patients with ALC in combination with obesity indicates a risk of thrombogenic conditions. This is also evidenced by the increasing number of D-dimers. Therefore, the fibrinolytic/antifibrinolytic factors should be considered in the treatment of such patients to prevent LC complications.

The inclusion of ademethionine, arginine glutamate and rosuvastatin in the treatment regimen for 3 months improved the levels of total protein, albumin, fibrinogen, PI, platelet count, Von Willebrand factor, PT, APTT, TT, INR, D-dimer, tPA and PAI-1, ADMA, which was accompanied by a decrease in Child-Pugh severity score and MELD 3-month mortality score.

Conclusions. Patients with ALC compared with obesity showed a decrease in total protein, albumin, fibrinogen, PI, platelet count and increased levels of Von Willebrand factor, PT, APTT, TT, INR, D-dimer, tPA and PAI-1, ADMA, which was accompanied by an increase in the Child-Pugh and MELD scores. A more pronounced increase in levels of PAI-1 and a decrease in tPA/PAI-1 index was noted, which indicates the risk of thrombogenic conditions in obese patients with LC. Inclusion of ademethionine, arginine glutamate and rosuvastatin in the treatment regimen of patients with LC in combination with obesity for 3 months improved total protein, albumin, fibrinogen, PI, platelet count, Von Willebrand factor, PT, APTT, TT, INR, D-dimer, tPA та PAI-1, ADMA, which was accompanied by a decrease in the ChildPugh severity score and MELD 3-month mortality score.

Conflict of interest. There is no conflict of interest regarding the research, authorship and/or publication of this article.

The work was performed in the framework of research work of Ivano-Frankivsk National Medical University of the Ministry of Health of Ukraine "Non-alcoholic fatty liver disease: impact on cardiovascular disease, treatment optimization" (state registration number 0118U004756), "Diseases of internal organs in modern conditions, combined pathology and lesions of target organs: features of the course, diagnosis and treatment" (state registration number 0115U000995).

\section{References}

1. Blasi A., Calvo A., Prado $V$. et al. Coagulation failure in patients with acute-on-chronic liver failure and decompensated cirrhosis: beyond the international normalized ratio // Hepatology. - 2018. - Vol. 68, N 6. - P. 2325-2337.

2. Bos S., Potze W., Siddiqui M. S. et al. Changes of in vitro potency of anticoagulant drugs are similar between patients with cirrhosis due to alcohol or non-alcoholic fatty liver disease // Thrombosis Research. - 2017. - T. 150. - P. 41-43.

3. Bos S., van den Boom B., Kamphuisen P. W. et al. Haemostatic profiles are similar across all aetiologies of cirrhosis // Thrombosis and haemostasis. - 2019. - Vol. 119, N 2. - P. 246-253.

4. Budimir I., Gradišer M., Nikolić M. et al. Glasgow Blatchford, pre-endoscopic Rockall and AIMS65 scores show no difference in predicting rebleeding rate and mortality in variceal bleeding // Scandinavian J. of Gastroenterology. - 2016. - Vol. 51, N 11. - P. 1375-1379. 
5. Fisher C., Patel V. C., Stoy S. H. et al. Balanced haemostasis with both hypo-and hyper-coagulable features in critically ill patients with acute-on-chronic-liver failure // J. of Critical Care. - 2018. - Vol. 43. - P. 54-60.

6. Hugenholtz G. C., Macrae F., Adelmeijer J. et al. Procoagulant changes in fibrin clot structure in patients with cirrhosis are associated with oxidative modifications of fibrinogen $/ / \mathrm{J}$. of Thrombosis and Haemostasis. - 2016. - Vol. 14, N 5. - P. 1054-1066.

7. Intagliata N. M., Argo C. K., Stine J. G. et al. Concepts and Controversies in Haemostasis and Thrombosis Associated with Liver Disease: Proceedings of the 7th International Coagulation in Liver Disease Conference: October 6th and 7th, 2017 Rome, Italy // Thrombosis and Haemostasis. - 2018. - Vol. 118, N 8. - P. 1491.

8. Intagliata N. M., Davis J. P. E., Caldwell S. H. Coagulationpath ways, hemostasis, and thrombosis in liver failure //Seminars in respiratory and critical care medicine // Thieme Med. Publishers. - 2018. - Vol. 39, N 5. - P. 598-608.

9. Kalambokis G. N., Oikonomou A., Christou L. et al. von Willebrand factor and procoagulant imbalance predict outcome in patients with cirrhosis and thrombocytopenia // J. of Hepatology. - 2016. - Vol. 65, N 5. - P. 921-928.

10. Kopec A. K., Joshi N., Luyendyk J. P. Role of hemostatic factors in hepatic injury and disease: animal models de-liver // J. of Thrombosis and Haemostasis. - 2016. - Vol. 14, N 7. P. 1337-1349.

11. Potze W., Siddiqui M. S., Boyett S. L. et al. Preserved hemostatic status in patients with nonalcoholic fatty liver disease //Journal of hepatology. - 2016. - Vol. 65, N 5. - P. 980-987.

12. Potze W., Siddiqui M. S., Sanyal A. J. Vascular disease in patients with nonalcoholic fatty liver disease // Seminars in Thrombosis and Hemostasis. - Thieme Medical Publishers. 2015. - Vol. 41, N 5. - P. 488-493.

13. Stine J. G., Niccum B. A., Zimmet A. N. et al. Increased risk of venous thromboembolism in hospitalized patients with cirrhosis due to non-alcoholic steatohepatitis // Clin. Transl. Gastroenterol. - 2018. - Vol. 9, N 3. - P. 140-147.

14. Vinholt P. J., Hvas A. M., Nielsen C. et al. Reduced platelet activation and platelet aggregation in patients with alcoholic liver cirrhosis // Platelets. - 2018. - Vol. 29, N 5. - P. 520-527.

15. Yilmaz V. T., Dincer D., Avci A. B. et al. Significant association between serum levels of von Willebrand factor (vWF) antigen with stages of cirrhosis // The Eur. J. of Med. - 2015. Vol. 47, N 1.- P. 21.

\section{ЗМІНИ ПОКАЗНИКІВ СИСТЕМИ ГЕМОСТАЗУ \\ У ХВОРИХ НА АЛКОГОЛЬНИЙ ЦИРОЗ ПЕЧІНКИ ТА ОЖИРІННЯ ПІД ВПЛИВОМ ЛІКУВАННЯ $З$ ВИКОРИСТАННЯМ АДЕМЕТІОНІНУ, АРГІНІНУ ГЛУТАМАТУ ТА РОЗУВАСТАТИНУ}

\section{Н. Р. Матковська (Івано-Франківськ)}

В даній роботі для оцінки ефективності тримісячної схеми лікування з включенням адеметіоніну, аргініну глутамату та розувастатину у хворих на алкогольний цироз печінки (АЦП) у поєднанні з ожирінням використано показники синтетичної функції печінки та системи гемостазу (загальний білок, альбумін, фібриноген, кількість тромбоцитів, фактор Віллебранда, протромбіновий час (ПЧ), активований частковий тромбопластиновий час (АЧТЧ), тромбіновий час (ТЧ), міжнародне нормалізоване відношення (МНВ), протромбіновий індекс (PI), D-димери, тканинний активатор плазміногену (tPA), інгібітор активатора плазміногену 1-го типу (PAI-1), відношення tPA/PAI-1, асиметричний диметиларгінін (ADMA), а також показники тяжкості цирозу печінки (index Child-Pugh) та індекс 3-місячної летальності MELD. Виявлено зниження рівнів загального білку, альбуміну, фібриногену, PI, кількості тромбоцитів та збільшення рівнів фактору Віллебранда, ПЧ, АЧТЧ, ТЧ, МНВ, PI, D-димерів, tPA та PAI-1, ADMA. Такі зміни погіршувалися з наростанням декомпенсації ЦП і супроводжувалися збільшенням показників індексів Child-Pugh та MELD $(\mathrm{P}<0,05)$. Нами відзначено більш виражене збільшення рівнів PAI-1, ніж tPA, що супроводжувалося зменшенням tPA/PAI-1 індексу. Ряд дослідників вказують, що збільшення рівнів ІАП-1 може викликати гіперкоагуляційний стан, тому виявлене його збільшення зі зменшенням tPA/PAI-1 індексу у хворих на АЦП в поєднанні з ожирінням вказує на ризик тромбогенних станів. Про це також свідчить наростатня D-димерів. Тому, при курації таких пацієнтів слід враховувати стан фібринолітичних/антифібринолітичних факторів для попередження усклад- 
нень цирозу печінки. Включення в схему лікування адеметіоніну, аргініну глутамату та розувастатину протягом 3 міс дозволило покращити показники загального білку, альбуміну, фібриногену, РІ, кількості тромбоцитів, фактору Віллебранда, ПЧ, АЧТЧ, ТЧ, МНВ, РІ, D-димерів, tPA та PAI-1, ADMA, що супроводжувалося зменшенням показників шкали тяжкості Чайльд-П'ю та індексу 3-місячної летальності MELD.

Ключові слова: алкогольна хвороба печінки; цироз печінки; ожиріння; гемостаз.

\section{ИЗМЕНЕНИЕ ПОКАЗАТЕЛЕЙ СИСТЕМЫ ГЕМОСТАЗА У БОЛЬНЫХ С АЛКОГОЛЬНЫМ ЦИРРОЗОМ ПЕЧЕНИ И ОЖИРЕНИЕМ ПОД ВЛИЯНИЕМ ЛЕЧЕНИЯ С ИСПОЛЬЗОВАНИЕМ АДЕМЕТИОНИНА, АРГИНИНА ГЛУТАМАТА И РОЗУВАСТАТИНА}

\section{Н. Р. Матковская (Ивано-Франковск)}

В данной работе для оценки эффективности трёхмесячной схемы лечения с включением адеметионина, аргинина глутамата и розувастатина у больных с алкогольным циррозом печени (АЦП) в сочетании с ожирением использовано показатели синтетической функции печени и системы гемостаза (общий белок, альбумин, фибриноген, количество тромбоцитов, фактор Виллебранда, протромбиновое время (ПВ), активированное частичное тромбопластиновое время (АЧТВ), тромбиновое время (ТВ), международное нормированное отношение (MHO), протромбиновый индекс (PI), D-димеры, тканевый активатор плазминогена (tPA), ингибитор активатора плазминогена 1-го типа (PAI-1), отношение tPA/PAI-1, aсcиметрический диметиларгинин (ADMA)), а также показатели тяжести цирроза печени (index Child-Pugh) и индекс 3-месячной летальности MELD. Выявлено снижение уровня общего белка, альбумина, фибриногена, PI, количества тромбоцитов и повышение уровня фактора Виллебранда, ПВ, АЧТВ, ТВ, MHO, PI, D-димеров, tPA и PAI-1, ADMA. Такие изменения ухудшались с наростанием декомпенсации цирроза печени и сопровождались увеличением показателей индексов Child-Pugh и MELD ( $<$ 0.05). Нами отмечено более выраженное повышение уровня PAI-1, чем tPA, что сопровождалось уменьшением tPA/PAI-1 индекса. Ряд исследователей указывают, что повышение уровня PAI-1 может вызвать гиперкоагуляционное состояние, поэтому обнаруженное его увеличение с уменьшением tPA/PAI-1 индекса у больных с АЦП в сочетании с ожирением указывает на риск тромбогенных состояний. Об этом также свидетельствует нарастание D-димеров. Поэтому, при курации таких пациентов следует учитывать состояние фибринолитических/антифибринолитических факторов для предупреждения осложнений цирроза печени. Включение в схему лечения адеметионина, аргинина глутамата и розувастатина в течение 3 мес позволило улучшить показатели общего белка, альбумина, фибриногена, PI, количества тромбоцитов, фактора Виллебранда, ПВ, АЧТВ, ТВ, MHO, PI, D-димеров, tPA и PAI-1, ADMA, что сопровождалось уменьшением показателей шкалы тяжести Чайльд-Пью и индекса 3-месячной летальности MELD.

Ключевые слова: алкогольная болезнь печени; цироз печени; ожирение; гемостаз. 